\title{
Management of root dilaceration in a central incisor after avulsion of primary tooth: a case report with a 6-year follow-up
}

\section{Manejo de dilação radicular em incisivo central permanente após avulsão do decíduo: relato de 6 anos de acompanhamento}

\begin{abstract}
Purpose: To describe the management and six-year follow-up of a patient who suffered trauma in primary dentition and, as a consequence, presented root malformation in permanent tooth.

Case description: A 5-years-old boy sustained trauma in primary maxillary anterior teeth due to a bicycle fall. As consequence of avulsion of left central incisor, the boy presented root dilaceration of the permanent successor. Radiography and clinical monitoring of the case were regularly performed. The tooth completed its eruption one year after sequel was detected and is currently successfully functional in the arch, despite the malformation.

Conclusion: This case reinforces the need of long term follow-up in order to avoid any risks of further tooth damage, intervening only when necessary.
\end{abstract}

Key words: Tooth injuries; primary teeth; sequelae

\section{Resumo}

Objetivo: Descrever o acompanhamento de seis anos de um paciente que sofreu trauma na dentição decídua e, como conseqüência, apresentou malformação radicular do sucessor permanente.

Descrição do caso: Um menino de 5 anos traumatizou o incisivo central superior durante queda de bicicleta. Como consequência da avulsão do incisivo esquerdo, houve a dilaceração radicular do sucessor permanente. Foi realizado o acompanhamento periódico clínico e radiográfico. $\bigcirc$ dente completou sua erupção um ano após a seqüela foi detectada e apresenta-se funcional no arco, apesar da malformação.

Conclusão: Esta caso reforça a necessidade do acompanhamento a longo prazo e de intervirse apenas quando realmente necessário, visando evitar danos ao dente permanente.

Palavras-chave: Injúrias dentárias; dentes decíduos; sequelas

\author{
Dione Dias Torriani a \\ Elaine de Fatima Zanchin Baldisseira ${ }^{b}$ \\ Marília Leão Goettems ${ }^{a}$
}

a Department of Social and Preventive Dentistry, Federal University of Pelotas, Pelotas, RS, Brazil ${ }^{b}$ Department of Clinical and Diagnostic Oral Sciences, Federal University of Pelotas, Pelotas, RS, Brazil

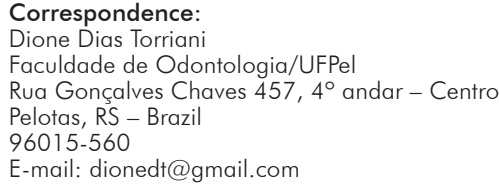

Conflict of Interests: The authors state that there are no financial and personal conflicts of interest that could have inappropriately influenced their work.

Copyright: (c) 2011 Torriani et al.; licensee EDIPUCRS. This is an Open Access article distributed under the terms of the Creative Commons AttributionNoncommercial-No Derivative Works 3.0 Unported License. 


\section{Introduction}

Traumatic dental injuries are common among children in primary dentition and are related to possible sequelae affecting the permanent succedaneous teeth (1). It is recognized that damage limitation and sequelae prevention in the developing tooth germ should guide dental trauma treatment in primary dentition (2).

The developmental disturbances in permanent teeth caused by trauma in their predecessors have a prevalence that ranges from $12 \%$ to $74 \%$ (3). The effects on permanent successors vary according to type of injury, the direction and intensity of impact (4) and the successor odontogenesis stage at the time of primary tooth injury (5).

Coronal abnormalities in the permanent teeth are more commonly associated with traumatic injury to primary teeth, whereas root abnormalities are relatively rare (6). Root sequelae usually occurs in children who sustain the injury between 4 and 5 years of age, due to a greater probability of affecting the successor's developing germ in the initial stages of root formation (Nolla's stage 6). It includes root duplication, dilacerations and partial or complete arrest of root formation $(3,4)$.

Dilaceration is defined as a deviation or bend in the linear relationship of the crown of a tooth in relation to its root (7). Although this alteration is not common, it does pose a number of diagnostic, management, and prognostic challenges to dental practitioners (8). This case report presents the 6-year follow-up of a case of root dilaceration in a permanent incisor caused by primary tooth avulsion.

\section{Case description}

A 5-year-old boy was taken to the Dentistry School Infant Clinic Unit (Federal University of Pelotas, RS, Brazil) by his mother in July 2003, presenting anterior tooth trauma due to a bicycle fall. The boy received initial care in the Emergency Room. There, his soft tissue was sutured and maxillary right central incisor exodontia was performed due to severe extrusion.

With his mother's consent, an anamnesis was carried out. The child was in good general health. Clinical and radiographic examinations (Fig. 1) were performed and upper left central and lateral incisor avulsion was diagnosed. The mother was warned of the need to keep the affected area clean so as to obtain good healing and was informed of possible complications in permanent tooth development. Follow-up controls were performed according to the guidelines for the management of traumatic, of International Association of Dental Trauma (9).

By April, 2005, 21 months after trauma occurrence, the permanent upper left central incisor showed radiographic alteration suggestive of either ankylosis, arrested root formation, or root malformation/dilaceration. The periodontal ligament was not identified and the presence of a root canal was not clear. The right central incisor showed normal development (Fig. 2). Extraction of the tooth had been considered as a treatment choice once there was a chance the tooth would not complete eruption. However, radiographic and clinical monitoring of the case for a longer period was chosen in order to avoid any risks of further damage (9).

After six months (October, 2005), tooth 21 had started eruption. There was no clinical sign of mobility, showing adequate periodontal support, and no sign of necrosis. Radiographic examination confirmed the diagnosis of root dilaceration (Fig. 3)

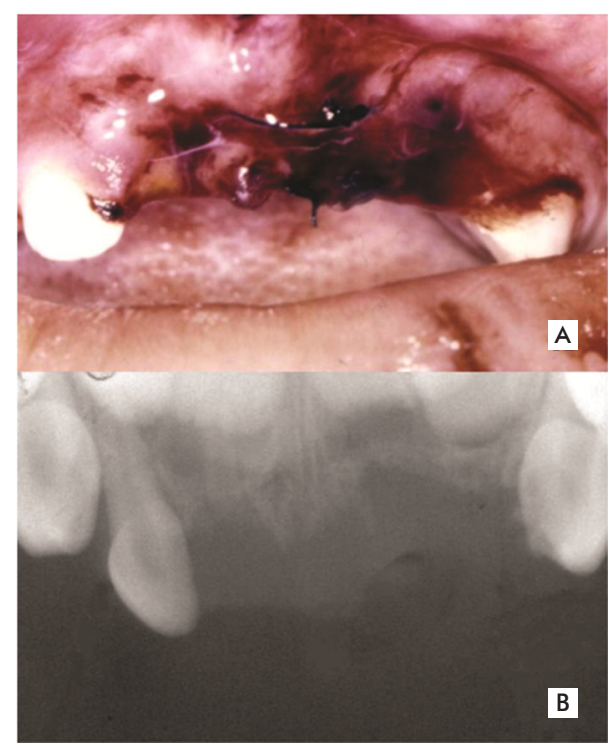

Fig. 1. (A) Clinical aspect in the first appointment. (B) Upper occlusal X-ray in the first appointment.

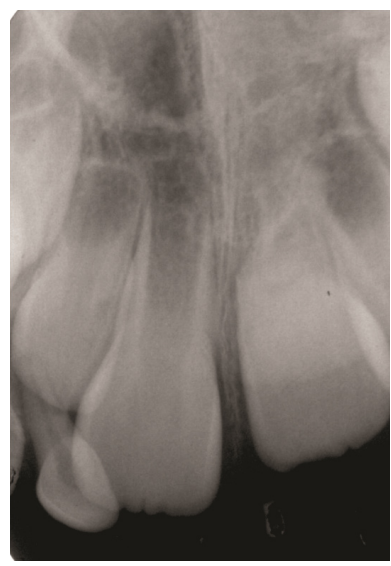

Fig. 2. Radiographic examination at the 21 -month follow-up.

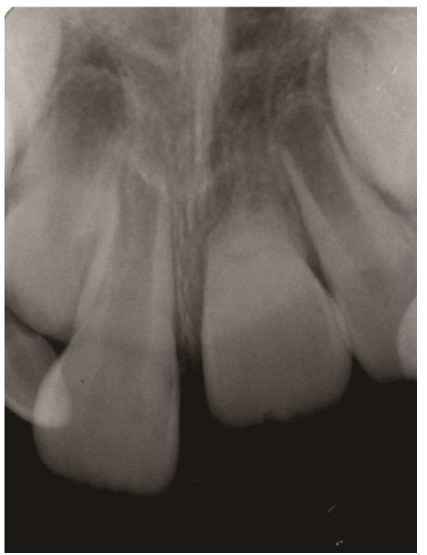

Fig. 3. Radiographic examination showing root dilaceration of central left incisor. 
In the 46-month follow-up (May 2007), despite a slight change in normal position, the crown fully erupted (Fig. 4). Figures 5 and 6 shows the patient six years after trauma occurrence (December 2009) with dilacerated tooth maintenance. The patient had small enamel fractures in the central upper right and left permanent incisors. There was no esthetic complaint from the family, so repair will be carried out as soon as occlusion is established.

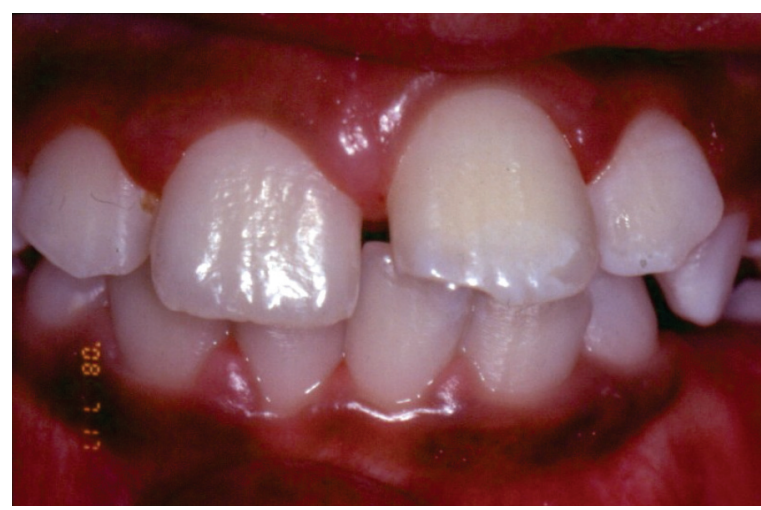

Fig. 4. Clinical examination showing complete eruption of the central incisors.

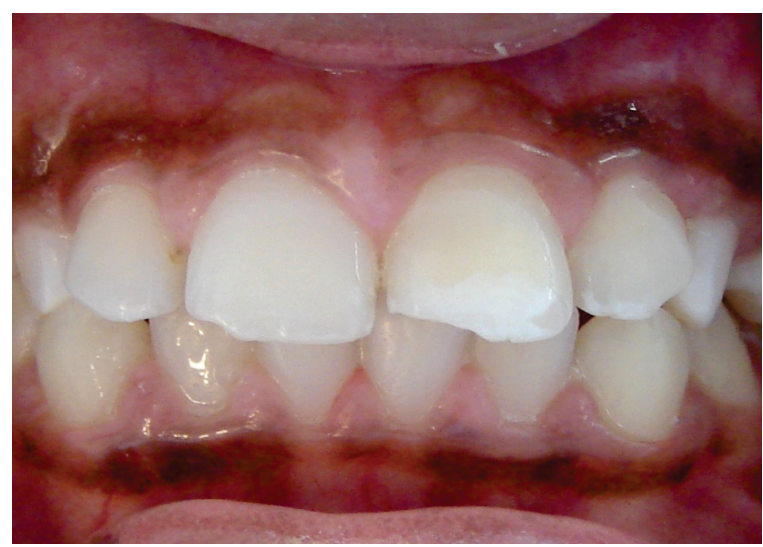

Fig. 5. Clinical examination 6 years after trauma occurrence.

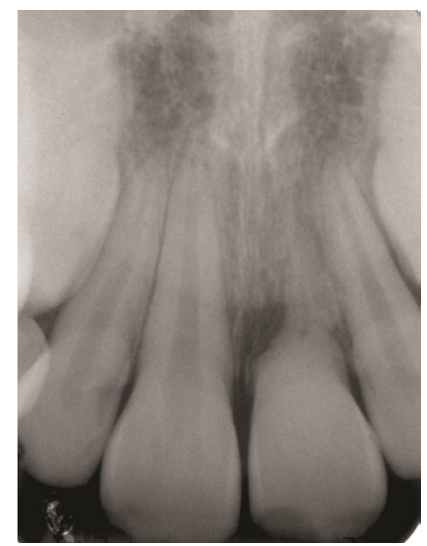

Fig. 6. Radiographic examination 6 years after trauma occurrence.

\section{Discussion}

The germs of the permanent incisors are in very close proximity to the roots of their predecessors, thereby predisposing these developing permanent teeth to secondary injuries when the deciduous are traumatized (10). Damages are more common after intrusion (3); however, they can also occur after primary predecessor avulsion, once the buccal curvature of the primary incisor root causes a slight rotation movement to avulse the tooth (11).

The permanent tooth germ is more susceptible to injuries in its early developmental stages (11), when the age of the child at the time of trauma is below 2, during Nolla's stages 1-3. Root malformation is more common when trauma occur between 4 and 5 years of age (4), showing that the type of developmental disturbances can correlate with the time at which the primary teeth sustained the injury. Trauma to the epithelial root sheath of Hertwig during root development may lead to root dilaceration or to an arrest of root formation (4).

For Ziberman et. al, the severity of the trauma is more important than the developmental stage of the tooth to determine the severity of root malformation. The authors investigated effects of trauma to the primary incisors on the root development of their permanent successors. Disturbances appeared in teeth that were traumatized between Nolla's developmental stages 2 and 8 (12).

Assunção et al. analyzed 623 permanent teeth from patients who suffered luxation injuries in the primary dentition. A frequency of $126(20.2 \%)$ permanent teeth with developmental disturbances was observed. From these, crown dilacerations were detected in three teeth and root dilaceration in one case only (13). A higher sequela occurrence was found by Jácomo \& Campos $(51,1 \%)$ (3). Out of 89 permanent successors affected, 14 teeth presented root dilaceration. From these, six were caused by intrusion in children who were between 3 and 5 years old.

Dilaceration might occur anywhere along the root length, or just at the root apex, and this depends on the root formation extent by the time of injury. Depending on the position of the tooth and severity of dilaceration, the noneruption of the affected tooth into the oral cavity, the primary predecessor tooth prolonged retention or labial cortical plate apical fenestration may occur.

Tewari and Pandey reported the case of a girl who presented root hypoplasia and various abnormalities of permanent incisors after primary incisors avulsion, which occurred at the age of 4 years and 8 months. As the mobility and proclination of the incisors was affecting aesthetics and hamper function, the extraction of the malformed teeth along with appropriate functional space maintenance and future prosthetic rehabilitation was chosen (14).

Sakai et al. described the case of a 3-year-old girl whose primary central incisor was avulsed, replanted 1 hour after the trauma and extracted three years later. When the patient was 10-year-old, the impaction and dilaceration of the maxillary right permanent central incisor was observed. The 
tooth was then surgically removed, and an esthetic fixed appliance was constructed with the crown of the extracted tooth (15).

In this case, root dilaceration occurred in a patient who sustained an injury at age 5 years-old. The affected tooth presenting root dilaceration spontaneously erupted and remained asymptomatic, without mobility or aesthetics damage. The family was advised of the morphological change and of the necessity of monitoring the tooth. Besides that, they were informed that the dilaceration may pose a challenge in case the tooth needs endodontic treatment or if the boy receives orthodontic treatment.
The case here presented reinforces the long term followup need in order to detect and minimize sequelae, intervening only when necessary. Most times, this procedure will lead to a better prognosis, which can minimize cost to parents. It is important that more invasive procedures are performed only when profession is certain they are required. Although exodontia was considered as a treatment choice, a watchand-wait approach was adopted, once this treatment would be irreversible. Thus, dentists must encourage conservative treatments rather than extraction or prosthetic treatment approach for more functional and esthetic results. Favorable results were achieved with a cautious approach.
References
1. Carvalho JC, Vinker F, Declerck D. Malocclusion, dental injuries and dental anomalies in the primary dentition of Belgian children. Int J Paediatr Dent 1998;8:137-41.

2. Lenzi AR, Medeiros PJ. Severe sequelae of acute dental trauma in the primary dentition--a case report. Dent Traumatol 2006;22:334-6.

3. Jácomo D, Campos V. Prevalence of sequelae in the permanent anterior teeth after trauma in their predecessors: a longitudinal study of 8 years. Dent Traumatol 2009; doi: 10.1111/j.1600-9657.2009.00764.x.

4. von Arx T. Developmental disturbances of permanent teeth following trauma to the primary dentition. Aust Dent J 1993;38:1-10.

5. Tozoglu S, Yolcu U, Tozoglu U. Developmental disturbance of maxillary lateral incisor after trauma. Dent Traumatol 2007;23:85-6.

6. Andreasen J, Andreasen, FM. Textbook and color atlas of traumatic injuries to the teeth. Copenhagen: Munksgaard; 1991.

7. von Gool AV. Injury to the permanent tooth germ after trauma to the deciduous predecessor. Oral Surg Oral Med Oral Pathol 1973;35:2-12.

8. Jafarzadeh $H$, Abbott PV. Dilaceration: review of an endodontic challenge. J Endod 2007;33:1025-30.

9. Flores MT, Malmgren B, Andersson L. Guidelines for the management of traumatic dental injuries. III. Primary teeth. Dent Traumatol 2007;23:196-202.

10. Andrade MG, Weissman R, Oliveira MG, Heitz C. Tooth displacement and root dilaceration after trauma to primary predecessor: an evaluation by computed tomography. Dent Traumatol 2007;23:364-7.

11. Christophersen P, Freund M, Harild L. Avulsion of primary teeth and sequelae on the permanent successors. Dent Traumatol 2005;21:320-3.

12. Zilberman Y, Fuks CD, Bassat YB, Brin I, Lustmann JL. Effect of trauma to primary incisors on root development of their permanent sucessors. Pediatr Dent 1986;8:289-93.

13. Assunção L, Ferelle A, Iwakura M, Cunha R. Effects on permanent teeth after luxation injuries to the primary predecessors: a study in children assisted at an emergency service. Dent Traumatol 2009;25:165-70.

14. Tewari N, Pandey RK. Root hypoplasia: an unusual sequela to primary tooth trauma. Dent Traumatol 2010;26:115-7.

15. Sakai VT, Moretti AB, Oliveira TM. Replantation of an avulsed maxillary primary central incisor and management of dilaceration as a sequel on the permanent successor. Dent Traumatol 2008;24:569-73. 